\title{
Conceptualisation of Ubuntugogy as a Decolonial Pedagogy in Africa
}

\author{
Bunmi Isaiah Omodan*1 \& Nolutho Diko ${ }^{1}$ \\ 1. Faculty of Education, Walter Sisulu University, South Africa \\ *Corresponding Author: bomodan@wsu.ac.za
}

Received : 2021-07-23

Rev. Req. : 2021-08-30

Accepted : 2021-09-16

How to cite this paper: Omodan, B. I. \& Diko, N. (2021). A Conceptualisation of Ubuntugogy as a Decolonial Pedagogy in Africa. Journal of Culture and Values in Education, 4(2), 95-104. https://doi.org/10.46303/jcve.2021.8

This is an Open Access article distributed under the terms of the Creative Commons Attribution 4.0 International license (https://creativecommons.org/licenses/by/4.0/)

\begin{abstract}
The concept of ubuntugogy appears as an ordinary grammatical prowess to some, while it also remains unknown to many. This conceptual paper attempts to conceptualise ubuntugogy, not only as indigenous teaching and learning but also as a decolonial pedagogy with liberating potentials. An assumption exists that today's pedagogical process in Africa is still laced with subjectivism, and it fails to challenge the Eurocentric hegemony that lies within school systems. The failure to address Eurocentrism explicitly leads to the need for ubuntugogy. Ubuntugogy, therefore, needs to be unpacked for better understanding. That is, this study is not to challenge the hegemony of westernised classrooms and their pedagogical process in Africa but to conceptualise the hidden potential of ubuntugogy to fill out the limited literature of the concept in the world of academics. Hence, the study provides answers to questions such as; what is ubuntugogy? What is the epistemology of ubuntugogy? What are the transformative tendencies of ubuntugogy, and how does ubuntugogy relevant in 21st Century classrooms? The study concluded that the idea of ubuntugogy is to create a learning environment where everyone feels empowered, encouraged and free from the burdens of Eurocentric and Americentric imposition with an open tendency of knowing and being human.
\end{abstract}

Keywords: Ubuntugogy; decoloniality; pedagogy; alternative pedagogy. 


\section{Introduction}

Decolonial pedagogy signals the need to explore decolonisation's pedagogical potentials as an emancipatory project, most especially in Africa. Decolonisation as a critical concept offers a theoretical framework that conceptualises the processes by which European colonialism, through various means, has produced discourses that are either outright chauvinistic or flawed in its ethnocentric approaches to knowledge production and dissemination (Yúdice, 1996). Decoloniality is a critical approach that emphasises how colonial power works not only at the level of governance but also at the level of representation: it dismantles simplistic binaries between coloniser/colonised/native to reveal how local populations have been marginalised by discourse and have actively resisted such categorisations (Ndlovu-Gatsheni, 2013; Seroto, 2018). Though, the concept of decoloniality is an oft-misunderstood concept that often refers to the practices, theories and philosophies resulting from various projects of decolonisation in order to regain ontological density, land, voices, place, culture, history and study to their original inhabitants towards knowledge and power (Cherry-Gertzel, 2015).

Deducing from the dynamics of decoloniality, one could then perceive that decolonial pedagogy is an idea that seeks to reveal how colonisation has affected the world we live in through a critical lens where knowledge production lies outside of Eurocentrism, thus acknowledging local politics within educational contexts. That is, decolonial pedagogy profoundly adheres and contributes to decolonial theory, which is a theory that highlights how colonial practices have oppressed the mass of colonised countries, not only through physical colonisation but also through discourse and knowledge imposition (Comaroff \& Comaroff, 1991; Oelofsen, 2015). In our reasoning, the decolonial theory of pedagogy can be defined as an epistemological framework where decolonial approaches are used to assess education phenomena, where western knowledge and power systems are being challenged to empower those often marginalised silenced by western forms of imperialism. In this case, one could argue that the best form of decolonial pedagogy is what ubuntugogy represents.

This definition confirms that decolonial pedagogy, otherwise called ubuntugogy in this study, seeks understanding for the individual, community or group who is left out by dominant western narratives, oppressive institutions to address the issues surrounding knowledge production, which result in its domination by neo-colonial forces. Thus, decoloniality is challenging how knowledge is produced to unveil the many ways in which Eurocentrism has distorted the original meaning of curriculum as a way of knowing, learning and passing down knowledge from generation to generation. This is especially important because curricula have been abused by dominant western interests to serve their own purposes. However, Curriculum Theory has shifted its focus from the curriculum as an end product (i.e., book or syllabus) towards curricula as practices, processes and experiences between teachers, students and institutional policies (Lindén et al., 2017). However, it still fails to directly challenge the Eurocentric hegemony that lies within school systems all around the (western) world, and mostly in Africa. This failure to address Eurocentrism explicitly leads to the need for ubuntugogy, which was coined from the word Ubuntu, an Africanised Philosophy (Beets \& Le Grange, 2005). Hence, this study is not to challenge the hegemony of westernised classrooms and their pedagogical process but to conceptualise the hidden potential of ubuntugogy and to contribute to the limited literature of the concept in academics. 


\section{Research Objective and Questions}

In this paper, we argue that the proper concept to replace decolonial pedagogy is ubuntugogy. Therefore, we outline the literature evidence relating to the concept of Ubuntugogy, epistemology of ubuntugogy, transformative tendencies ubuntugogy, and the relevance of ubuntugogy in $21^{\text {st }}$ Century classrooms. Through reasoned discourse, the following questions were answered using literature-based argument:

- What is ubuntugogy?

- What is the epistemology of ubuntugogy?

- What are the Transformative tendencies of ubuntugogy?

- And how does ubuntugogy relevant in $21^{\text {st }}$ Century classrooms?

\section{What is Ubuntugogy?}

Before examining the pedagogy of Ubuntu (ubuntugogy), it is critical to highlight that there is no singular definition that could be accorded to it from literature. But then, the pedagogy of Ubuntu (ubuntugogy) could be seen as an approach that emerges from the values of Ubuntu, a postcolonial concept which addresses community and individual identity in African philosophy (Omodan, 2019, Omodan \& Ige, 2021a). Paulo Freire's philosophies on education also inform this approach to reveal its central values as they relate to individualism, solidarity and humanism (Freire, 1996). Therefore, the value of Ubuntu emphasises a connectedness that sees the other not as one who lives separately but as one who lives with the fundamental recognition that the self depends upon others (Tsotetsi \& Omodan, 2020). It is an ethic or morality that is resonantly ingrained within people.

In the spirit of Ubuntu, this approach to learning and teaching is based on a relational formation whereby the social dimensions of learning are considered critical to individual development. Values such as solidarity and humanism are connected to "conscientisation" - the process by which people come to realise their power within society and tune in with others who experience similar oppression so that they can work together for change (Freire, 1996). Through dialogue, students have the opportunity to recognise their own history, culture, language and personal identity beyond what has been previously taught or prescribed by mainstream values. That is, the pedagogy of ubuntugogy also depends on a social interpretation and recognition of human histories and their peculiarities, which is significant to students' success (Donohue, 2020).

In this way, we argue that decoloniality has initiated a dialogue between the academic world of western education and various Indigenous knowledge systems that have been historically oppressed, beginning with European colonialism in all corners. And while respected by many intellectuals around the world, decoloniality is still to be recognised as a legitimate approach to pedagogy within educational curricula nationally or internationally. Therefore, ubuntugogy is a teaching and learning (educational practice) where people are empowered to recognise their own history beyond colonisation which seeks to erase any Afro-European epistemological differences. In order to understand the origin of knowledge in regards to ubuntugogy, the following session discusses the epistemology of ubuntugogy. 


\section{Resonating the Epistemology of Ubuntugogy}

The pedagogy of ubuntugogy is a teaching and learning system which bases its epistemology on African-ness, African values, beliefs and ideas. In addition, ubuntugogy tends to privilege experience, history, culture and environmentalism over the documented disposition of knowledge as an avenue for knowing. Ubuntugogy supports the use of local languages instead of foreign or European languages as mediums for instruction or systems of communicating information in class. Therefore, this reflection focuses primarily on how ubuntu philosophy may result in widespread improvement in educational outcomes at all levels of education by presenting a new paradigm for educational practices.

Ubuntugogy is a knowledge development strategy that the African people developed as a response to Western domination and imperialism (Bangura, 2005; van der Walt, 2010; Bangura, 2017). This idea leads me to argue that it is an Africanized teaching and learning system that derives its contents from African values, beliefs, and ideas such as ubuntu philosophy, emphasising human relationships, kinship (humanity), community spirit, and social justice (Kruger, 2016). Its epistemology privileges experience over mere bookish information in order to develop capabilities for self-reliance. Thus, it encourages free discussion among students using local languages that students are more comfortable with to suggest solutions for problems in their mother tongue or indigenous language rather than Euro-Americentric languages. In this way, ubuntugogy creates solidarity and unity among students, which promotes collective learning and collaborative effort to achieve the set objectives of the class or lecture room. Therefore, this method of knowledge development is a repository of African thoughts and ideals that advocate communalism, individuality, social justice, and humanism (Assié-Lumumba, 2017).

To further explain the epistemological praxis of ubuntugogy, there is a need to also conceptualise it within some classroom transformative agender such as; classroom liberation, the values it possesses, as participatory experiences, and a tool for collaborative engagement.

\section{Ubuntugogy as a Classroom Liberation}

In this session, we present my argument to justifying that ubuntugogy is a movement for liberation in teaching and learning. This is because it is based on the concept of Ubuntu as it does not mean any specific way or technique to teach or learn but is based on the idea that it is easier to find truth through mutual sharing and interaction among members. Ubuntugogy is meant to feel what others are feeling, especially the students. One must always consider how to serve others at first before self-serving things. This teaching principle will allow teachers to share their knowledge with students by confronting them with facts, considering, giving solutions, and giving room for discussion. In addition, ubuntugogy provides freedom and flexibility in a learning environment, enhancing the student's creativity, independence, and freedom to explore or innovate. From this argument, one could consider it a concept that gives values of caring for others to be human beings since it emphasises collaboration among students and teachers (Ferreira \& Schulze, 2014). This is a kind of teaching movement that embraces all cultures from different backgrounds in order to build up the unity of each one by accepting differences even with minor conflicts. This is perhaps what Muste (2016) referred to as a productive communication process between teacher and students while encouraging them 
to make their own decisions; solve their problems on their own without influencing the other; sharing their ideas with the ones who are involved or those can affect directly or indirectly.

In this form of classroom practices, emphasis is laced on the action, reflection, commitment, and practice of making changes to society by changing from what it is to become what we wish for the future generation. On the critical thinking aspect, ubuntugogy also reflects on critical thinking where students learn not just in order to pass their exams but, more importantly, learn for the change, growth, creativity and freedom through actions for others (Venter, 2004; Hungwe, 2021). This is to argue that ubuntugogy classes are built up in an interactive learning process that focuses on self-learning that adds meaning and excitement to the subject being taught. Such an atmosphere incorporates that all members are involved directly or indirectly in the teaching process and require others to be responsible, respectful, and caring. Having said this, one could then further the argument that the ideology of ubuntugogy lies in the fact that it motivates students not only into thinking but also into action, investigating what they know about something, values, and vision about something or someone and has a commitment for oneself.

\section{Ubuntugogy as a Concept of Shared Values}

Ubuntu philosophy as the underlying dynamic concept includes Shared Values, compassion, empathy, humanness, and interconnectedness (Mabovula, 2011). Ubuntugogy has been justified in that it adopts democratic principles and offers an alternative to conventional educational practices, which tend to promote student's tolerance towards understanding different experiences and backgrounds (Omodan \& Ige, 2021b). It also promotes a democratic classroom environment where teachers are facilitators who support students in developing skills necessary for participative decision-making processes (Omodan \& Tsotetsi, 2019; Sambala et al., 2020; Omodan, 2020). This may not be unconnected with the fact that it focuses on more than one way of learning; therefore, it does not marginalise those who are slow learners or have some disability, for example, deafness. This argument is also compatible with the SADC Protocol on School Health and safety that was developed in 2003 comprising South Africa, Botswana, Lesotho, Malawi, Mozambique, Namibia, Seychelles, Swaziland, Zambia and Zimbabwe to support students to develop skills that will assist them in dealing effectively with abuse of alcohol and violence hence curtailing risky behaviours among young people (Nkowani, 2008).

\section{Ubuntugogy as a Participatory Experience}

Ubuntu practice also promotes sharing experiences as a way of learning instead of stressing on conventional methods like lectures whereby teachers impart knowledge to students who do not have an equal chance of interacting with other learners and teachers in the classroom (Chingombe, 2018; Gunawardena, 2020). Ubuntugogy is a philosophy that supports teachers to use appropriate methods of teaching in line with ubuntu principles so that more vulnerable groups like women, people from other tribes or the disabled are not neglected (Masondo, 2017). Ubuntugogy stresses on unity through diversity among students as they share their experiences and interact with each other during class in order for them to develop solidarity hence promoting unity which is one of the pillars of ubuntu philosophy (Venter, 2004). Ubuntugogy, therefore, supports shared leadership, democracy and participation in decision making processes to ensure that the majority makes all decisions of learners who can, in turn, 
contribute their ideas for better learning. It also supports giving students an opportunity to learn new things that they have never learned before by encouraging them to interact with fellow students and teachers (Rampa \& Mphahlele, 2016). This is to also argue that ubuntugogy advocates for a learner-centred classroom environment where the main focus is on the effective teaching-learning process, innovative approaches and student assessment through self-monitoring (Keane, 2008). Ubuntugogy promotes interaction among learners both in schools and out-of-school, e.g. during holidays through projects development to learn to work in groups and thus have equal opportunity to participate in all decision-making processes. This participatory idea of ubuntugogy as a philosophy, therefore, stresses equality among learners whereby learners are not discriminated against because of their gender, age or ethnic group but share ideas freely so that they can develop unity and tolerance towards other members in class hence promoting social justice which is one of the pillars of ubuntu philosophy (Ngubane \& Makua, 2021).

\section{Ubuntugogy as a Collaborative Engagement}

Ubuntu practice advocates for community participation involving learners, parents and teachers, whereby all members work together to learn new things through group discussions, joint learning (Hapanyengwi-Chemhuru \& Shizha, 2012). Thus, it could also be linked to a democratic classroom environment that ensures that all learners are given an opportunity to engage in joint projects within classrooms and promote their welfare, hence improving social justice. This idea undoubtedly promotes effective participatory methods of teaching, disseminating information using different media such as textbooks, radio and television, among others, to bring about development among schools and the entire community (Quan-Baffour \& Vambe, 2006; Hapanyengwi-Chemhuru \& Shizha, 2012). By doing so will encourage equal opportunities for access to knowledge like internet facilities at the school level as well as granting learners equal access to learning materials in order to promote equality among the learner hence promoting social justice, which is one of the pillars of ubuntu philosophy (Ngubane \& Makua, 2021). Such community feelings enhance a democratic classroom environment where teachers proactively listen to students' views and opinions on issues affecting them, thereby allowing them to participate actively in decision-making processes within the class. Ubuntugogy, therefore, makes it possible to integrate traditional knowledge, science and technology together so as to develop a suitable curriculum that suits community needs (Seehawer, 2018). Thus adopts a human-centred approach whereby it promotes sustainable development through quality citizens with moral integrity who shared their wealth with less privileged members.

\section{The Relevant of Ubuntugogy in $21^{\text {st }}$ Century Classroom}

To acknowledge the common humanity of all people and build a nation as one people, sharing their culture with one another. Relevant to this is the role that Ubuntu plays in education globally. As learners move into the 21st century learner-centred classrooms they need to recognise themselves as having the power to shape their own future. Globally, there needs to be an attitudinal change towards people outside one's immediate group or community, taking cognisance of the oneness of humankind and its cultural diversity. This attitude is central to ubuntu philosophy which calls for understanding and cooperation among peoples using ubuntugogy as an approach within a globalising world (Iline \& Phillip, 2019). 
In a globalising world, there is great belief that education systems are to provide the wherewithal for learners to be able to have the necessary skills and attitudes to navigate and emancipate themselves. For this goal to be achieved, ubuntu philosophy can provide a point of departure for educators seeking educational paradigms that will prepare their students to learn how to become active participants in an ever-globalising world. Most importantly, Ubuntu as a pedagogical approach and its values should not only feature on paper but should be imbibed by all learners so that they can appreciate other people's points of view; take responsibility for themselves; support others and accept one another as equals. At this point, one could argue that lack of ubuntugogy is tantamount to distorted and conflict-oriented pedagogy, which could result in hatred of race, culture, nationality, among others. Such suffixed in South African experience of xenophobia (Adjai \& Lazaridis, 2013; Dube \& Omodan, 2021). That is, the presence of ubuntugogy in schools will help to create inclusive pedagogy that will eliminate hatred and disunity among people. Relevant research shows that young people are more likely to be open-minded than other age groups concerning citizenship, loyalty, and identity (Pichler, 2009). This suggests that it might be especially important that educators should consider what kinds of social practices contribute towards a greater understanding of global issues among school children and how education may facilitate these kinds of changes.

\section{Conclusion}

From the foregoing, it is not out of content to conclude that ubuntugogy is a style of teaching and learning that gives priority to the voices of teachers and students on all sides of issues. From the decolonial perspective, one could conclude that ubuntugogy is a practical way to decolonise teaching and learning space where students and teachers are empowered to be active knowledge developers in their society. That is, the pedagogy of Ubuntu is very relevant to the current transformation agenda in the curriculum and classroom activities which aims at recognising these differences and attempting to assimilate them into one's own being-identity. This would enable teachers and learners to see a deeper sense of self-awareness beyond the surface level of appearances. The possibility of achieving this arises from an intersubjective relationship with one another. Therefore, ubuntugogy provides a decolonial pedagogy for the empowerment of all students and teachers in schools, at home, in society to liberate their potential as persons who are intellectually empowered as knowledge creators.

Furthermore, one could still say that ubuntugogy is premised on creating a learning environment where all learners have equal access to power to generate knowledge where the learners-teacher relationship is beyond subjectivity. Deducing from relationships devoid of subjective tendency assumes that every individual has value in herself/himself regardless of her/his skin colour, gender or another social status, and being open for dialogue about different ways of knowing and being human. This conclusion is in line with Wingfield's (2017) and Hall and Tandon (2017) argument that decolonising education is to eliminate colonial power and its centrality and replace it by restoring indigenous power and leadership. Perhaps, this is what Hove and Dube (2021) refer to as emancipative and transformative pedagogy. Hence, it is imminent to provide ubuntugogy as alternative teaching and learning that could reclaim native values as its own rather than those imposed on by Euro and Americentric hegemony (AlMahfedi, 2020). 


\section{References}

Adjai, C., \& Lazaridis, G. (2013). Migration, xenophobia and new racism in post-apartheid South Africa. International Journal of Social Science Studies, 1(1), 192-205. http://dx.doi.org/10.11114/ijsss.v1il.102

Al-Mahfedi, M. H. K. (2020). Cultural Hegemonic Discourse: From Imperialist Eurocentrism to Homogenizing Americentrism. International Journal of Linguistics and Translation Studies, 1(3), 20-34. https://doi.org/10.36892/ijlts.v1i3.94

Assié-Lumumba, N'Dri T. (2017). The Ubuntu Paradigm and Comparative and International Education: Epistemological Challenges and Opportunities in Our Field. Comparative Education Review, 16(1), 1-21.

Bangura, A. K. (2005). Ubuntugogy: an African educational paradigm that transcends pedagogy, andragogy, ergonagy and heutagogy. Journal of Third World Studies, 22(2), 1353.

Bangura, A. K. (2017). African-Centered Internet Literacy: An Ubuntugogy Metadata Approach. Journal of Pan African Studies, 10(10), 88-108.

Beets, P., \& Le Grange, L. (2005). Africanising' assessment practices: Does the notion of ubuntu hold any promise? South African Journal of Higher Education, 19(1), 1197-1207.

Cherry-Gertzel, O. A., (2015). This issue of the Australasian Review of African Studies is dedicated to Cherry Gertzel OA (1928-2015) Former Editor of the Australasian Review of African. Australasian Review of African Studies, 36(2), 1-50.

Chingombe, S. I. (2018). The use of cooperative learning strategies in pre-service secondary school teacher education at two state universities in Zimbabwe: a critical investigation (Doctoral dissertation, University of Kwazulu Natal).

Comaroff, J., \& Comaroff, J. (1991). Of Revelation and Revolution, Vol. 1: Christianity, Colonialism, and Consciousness in South Africa. Chicago: University of Chicago Press.

Donohue, D. (2020). Culture, cognition, and college: How do cultural values and theories of intelligence predict students' intrinsic value for learning? Journal of Culture and Values in Education, 4(1), 1-14. https://doi.org/10.46303/jcve.2020.3

Dube, B. \& Omodan, B. I. (2021). 'Struck from all sides' - Reliving the Lived Experiences of Immigrant Youths in the Context of Mafiarised Religions: Towards a Rehumanisation of Theology. Alternation, 34, 219-237. https://doi.org/10.29086/2519-5476/2020/sp34a12

Ferreira, C, \& Schulze, S. (2014). Teachers' experience of the implementation of values in education in schools: "Mind the gap". South African Journal of Education, 34(1), 1-13. http://www.scielo.org.za/scielo.php?script=sci_arttext\&pid=S0256$01002014000100008 \& \operatorname{lng}=e n \&$ tIng=en.

Freire, P. (1996). Pedagogy of the oppressed. New York: Continuum.

Gunawardena, C. N. (2020). Culturally inclusive online learning for capacity development projects in international contexts. Journal of Learning for Development, 7(1), 1-31.

Hall, B. L., \& Tandon, R. (2017). Decolonisation of knowledge, epistemicide, participatory research and higher education. Research for all, 1(1), 6-19.

Hapanyengwi-Chemhuru, O., \& Shizha, E. (2012). Unhu/Ubuntu and education for reconciliation in Zimbabwe. Journal of Contemporary Issues in Education, 7(2), 17-27. https://doi.org/10.20355/C5XW2D 
Hove, B., \& Dube, B. (2021). Covid-19 and the entrenchment of a virtual Elite private school: Rethinking education policies in Zimbabwe. Journal of Culture and Values in Education, 113. https://doi.org/10.46303/jcve.2021.5

Hungwe, J. P. (2021). The (In) compatible Nexus between Ubuntu and Critical Thinking in African Philosophy of Education: Towards Ubuntu Critical Thinking in African Higher Education. In Mediating Learning in Higher Education in Africa (pp. 23-40). Brill.

Iline, C. S., \& Phillip, H. (2019). Philosophical Reflections on Ubuntu in the Context of Cooperative Learning. International Research in Higher Education, 4, 10-24. https://doi.org/10.5430/irhe.v4n2p10

Keane, M. (2008). Science learning and research in a framework of Ubuntu. Available at https://www.researchgate.net/publication/291485664 Science Learning and Research in a Framework of Ubuntu\#fullTextFileContent

Kruger, E. A. (2016). An exploration of transformative piano teaching in Pretoria: a case study. (Master Thesis, North-West University, South Africa).

Lindén, J., Annala, J. and Coate, K. (2017), "The Role of Curriculum Theory in Contemporary Higher Education Research and Practice", Theory and Method in Higher Education Research (Theory and Method in Higher Education Research, Vol. 3), Emerald Publishing Limited, Bingley, pp. 137-154. https://doi.org/10.1108/S2056-375220170000003008

Mabovula, N. N. (2011). The erosion of African communal values: A reappraisal of the African Ubuntu philosophy. Inkanyiso: Journal of Humanities and Social Sciences, 3(1), 38-47.

Masondo, C. N. (2017). Enhancing the effectiveness of principals in implementing inclusive education using Ubuntu approach (Doctoral dissertation, University of the Free State).

Muste, D. (2016). The Role of Communication Skills in Teaching Process. In Selection and peer-review under responsibility of the Organizing Committee of the conference. The European Proceedings of Behavioral and Social Sciences EpSBS. http://dx.doi.org/10.15405/epsbs.2016.12.52

Ndlovu-Gatsheni, S. J. (2013). Empire, Global Coloniality and African Subjectivity. New York and Oxford: Berghahn Books.

Ngubane, N.I., \& Makua, M. (2021), 'Intersection of Ubuntu pedagogy and social justice: Transforming South African higher education'. Transformation in Higher Education 6(0), a113. https://doi.org/10.4102/the.v6i0.113

Nkowani, Z. (2008). Injury unto death: occupational health and safety regulation: a window on Malawi. Comparative and International Law Journal of Southern Africa, 41(1), 49-79. https://hdl.handle.net/10520/EJC24663

Oelofsen, R. (2015). Decolonisation of the African Mind and Intellectual Landscape. Phronimon, 16(2), 130-146.

Omodan, B. I. \& Ige O. A (2021b). Managing diversity in schools: The place of democratic education and Ubuntuism in South Africa. Journal for transdisciplinary research in Southern Africa, 17(1), a854. https://doi.org/10.4102/td.v17i1.854

Omodan, B. I. \& Ige, O. A. (2021a). Analysis of Ubuntu as a Transformative Strategy to Mitigate Social Unrest in the University system. Journal of Studies in Social Sciences \& Humanities. 7(2), 76-86.

Omodan, B. I. (2019). Defacing Machiavellianism in University Politics: A Discourse to Reconstruct Leadership through Ubuntu. African Renaissance, 16(4), 33-51. http://doi.org/10.31920/2516-5305/2019/16n1a2 
Omodan, B. I. (2020). Combatting the Imperativeness of Modernity in Students' Unrest: The Need to Decolonise the Minds through Ubuntu. International Journal of Higher Education, 9(4), 310-319. https://doi.org/10.5430/ijhe.v9n4p310

Omodan, T. C., \& Tsotetsi, C. T. (2019). Framing ubuntu philosophy to reconstruct principals' behaviour and teachers' effectiveness in secondary schools. Journal of Education Research and Rural Community Development, 1(1), 25-45. https://journals.co.za/doi/pdf/10.10520/EJC-19ade7e3de

Pichler, F. (2009). 'Down-to-Earth' Cosmopolitanism: Subjective and Objective Measurements of Cosmopolitanism in Survey Research. Current Sociology, 57(5), 704-732. https://doi.org/10.1177/0011392109337653

Quan-Baffour, K. P., \& Vambe, M. T. (2006). Multiculturalism and learning technologies in Adult Basic Education and Training programs at the University of South Africa. Research and practice in technology enhanced learning, 1(03), 297-308.

Rampa, S. H., \& Mphahlele, L. K. (2016). Supporting Open Distance Learning (ODL) students through Ubuntu values. Open Distance Learning (ODL) through the Philosophy of Ubuntu, 119-132.

Sambala, E. Z., Cooper, S., \& Manderson, L. (2020). Ubuntu as a framework for ethical decision making in Africa: Responding to epidemics. Ethics \& Behavior, 30(1), 1-13. https://doi.org/10.1080/10508422.2019.1583565

Seehawer, M. (2018). South African Science Teachers' Strategies for Integrating Indigenous and Western Knowledges in Their Classes: Practical Lessons in Decolonisation. Educational Research for Social Change, 7(0), 91-110. http://dx.doi.org/10.17159/22214070/2018/v7i0a7

Seroto, J. (2018). Dynamics of Decoloniality in South Africa: A Critique of the History of Swiss Mission Education for Indigenous People. Studia Historiae Ecclesiasticae, 44(3), 1-14. https://doi.org/10.25159/2412-4265/3268

Tsotetsi, C. T. \& Omodan, B. I. (2020). Deconstructing power differentials in a supervision process: Mentoring in Ubuntu perspective. Ubuntu: Journal of Conflict transformation, 9(1), 105-129. https://hdl.handle.net/10520/EJC-1eb5d4e406

van der Walt, J. L. (2010). " Ubuntugogy" For The 21 St Century. Journal of Third World Studies, 27(2), 249-266.

Venter, E. (2004). The Notion of Ubuntu and Communalism in African Educational Discourse. Studies in Philosophy and Education 23, 149-160. https://doi.org/10.1023/B:SPED.0000024428.29295.03

Wingfield, B. (2017). What "decolonised education" should and shouldn't mean. The conversation, 14.

Yúdice, G. (1996). Postcolonialism: An Historical Introduction. Cambridge: Blackwell. 